\title{
SHIFTING THE BURDEN OF INCOME TAXES BY CONTRACT
}

\section{By Louis M. Brown $\dagger$}

Income tax consequences are a material aspect of many financial transactions. Such transactions are frequently encouraged or discouraged because of the income tax consequences assumed to flow from them. 'An owner of land, for example, may be willing to sell at a gain if he feels certain that there will result a long-term capital gain, but may be unwilling to sell at the same price if he feels that the result will be a short-term gain. Yet guaranties of expected income tax consequences are rarely obtainable from the Federal Government. The availability of a closing agreement is severely limited. ${ }^{1}$ The avenue of declaratory relief is closed. ${ }^{2}$

Where one party to a transaction is uncertain as to the tax consequences, he may endeavor to shift his income tax risk to the other. Whether.such a tax-shifting covenant can be arranged depends primarily on the bargaining positions of the parties. Whenever such tax-shifting covenants become a part of the bargain, the practical effect is to substitute the financial ability of the obligor for the uncertain tax risk. Thus, for example, a buyer may induce a recalcitrant seller to sell his land if the buyer is willing to assume the seller's income tax burden. Such tax-shifting covenant may give the parties the impression that one of them, the seller, has concluded a transaction wherein he is tax-free. But a look beneath the surface will show that many a problem lurks below.

\section{Shift to the Paying Party}

The initial tax consequence of a tax-shifting covenant has been considered by the United States Supreme Court. In Old Colony Trust Company v. Commissioner, ${ }^{3}$ an employer agreed to pay, in addition to an employee's salary, the income taxes that might become due and

† A. B., 1930, University of Southern California; LL.B., 1933, Harvard University; member of Los Angeles Bar; author, The Effect of Conscription of Industry on Contracts for the Sale of Goods, 90 U. of PA. L. REv. 533 (1942).

1. 9 Mertens, Federal Income Taxation 450 et seq. (1943).

2. Wilson v. Wilson, 141 F. 2 d 599 (C. C. A. 4th 1944); 48 STAT. 955 (1934), 28 U. S. C. $\$ 400(1940)$.

3. 279 U. S. 716 (1929), 8 N. C. L. REv. 214 (1930). 
payable upon such salary. The question certified by the Circuit Court of Appeals for answer by the Supreme Court was: "Did the payment by the employer of the income taxes assessable against the employee constitute additional taxable income to such employee?" 4 The Court held that it did. On the same day, a like decision was handed down by the Supreme Court in a case in which a lessee covenanted to pay specified rentals plus all the lessor's income taxes upon the rental. The lessor was held to have received taxable income amounting to the specified rental plus the income taxes thereon. ${ }^{5}$ Thus was a firm basis laid for the principle, previously announced by lower courts ${ }^{6}$ and subsequently followed, ${ }^{7}$ that payment by one person of another's income tax may result in taxable income.

The situations in which one party, A, may pay the income taxes of another, $B$, are of course not confined to employer-employee and landlord-tenant relations. In any purchase and sale transaction a vendee may promise to pay the vendor's income tax. A corporation may pay the stockholder's income $\operatorname{tax}^{8}$ on dividends. ${ }^{8}$ A trust indenture may provide that the trustee pay the beneficiary's income tax on the income distributed to the beneficiary. ${ }^{10} \mathrm{~A}$ tax-shifting covenant may be employed in connection with the settlement of lawsuits. A plaintiff may be willing to compromise a claim for a lesser amount provided that the amount received is not income, but may be unwilling to compromise for such lesser sum if the total received is taxable income. Illustrative is a case in which the plaintiff sues for unfair competition, where it may be doubtful whether damages, when recovered,

4. Id. at 720 .

5. U. S. v. Boston \& M. R. R., 279 U. S. 732 (1929).

6. Providence \& Worcester R. R., 5 B. T. A. 1186 (1927); Houston Belt \& Terminal Ry., 6 B. T. A. 1364 (1927) ; Rensselaer \& S. R. Co. v. Irwin, 249 Fed. 726 (C. C. A. 2d 1918).

However, in Boston \& Maine R. R. v. United States, 23 F. 2d 343 (D. Mass. 1927), the court held that the lessor's original tax paid by the lessee was not income to the lessor and hence not taxable. The holding was criticized in $41 \mathrm{HARV}$. L. REv. 801 (1928). The case was reversed by the U. S. Supreme Court, supra, note 5.

7. Magill, Taxable Income 236 et seq. (rev. ed. 1936); 1 Merrens, Federal INCONIE TAXATION 393 (1942). Two special types of cases have been held on grounds of statutory interpretation not to create taxable income. (a) Taxes paid by the obligor of the bond under a so-called tax-free covenant in an indenture. U. S. Treas. Reg. 45, \$213(a), Art. 31; Revenue Act of 1918, \$221 (b), 40 STAT. 1057 (1918); (b) two per cent federal income tax paid by the Director General of Railroads. New York, O. \& W. Ry, 1 B. T. A. 1172 (1925). Both of these special situations are discussed in MAGILL, TAXABLE INCOME 238-241 (rev. ed. 1936).

8. Acme Coal Co. v. United States, 44 F. $2 d 95$ (Ct. Cl. 1930).

9. F. G. Lamb, 14 B. T. A. 814 (1928).

10. See Toretta v. Wilmington Trust Co., 71 F. Supp. 281 (D. Del. 1947) (court held that trust indenture did not, by its language, require trustee to pay beneficiary's income $\operatorname{tax}$ ). 
are taxable as recovery for lost profits or non-taxable as damages for lost capital. ${ }^{11}$

Notwithstanding the general principle that the payment by $\mathrm{A}$ to $B$ of the tax sum (herein sometimes designated $T$ ), in addition to the principal sum (herein sometimes designated $P$ ), produces further income to $B$, there are circumstances in which the payment of the tax sum does not produce additional income.

It has sometimes been asserted that the payment of the tax sum by $A$ to $B$ is a gift to $B$ rather than income to $B$. But if such payment is to be considered a gift, the circumstances must defeat the notion that such payment arises out of an obligation to pay; that it is, for example, not essentially compensation. ${ }^{12}$ Where such payment arises out of a commercial transaction, even though voluntarily made, it is rare to find that such payment will be regarded as a gift. ${ }^{13}$ In other cases, it has been asserted that the tax sum payment by $A$ to $B$ is a loan rather than income to $B$. Where the facts support this contention, the taxpayer has met with success. ${ }^{14}$ At other times the taxpayer, $B$, has sought to show that the tax sum payment is not taxable income on the ground that the payment is a contribution to capital. ${ }^{15}$ In an unusual case, a tax payment made on behalf of a partner by the other partners, as the result of an arrangement between them determining the amounts which each was to pay for income tax deficiencies arising out of the partnership affairs, was held to be a capital contribution. ${ }^{16}$

\section{Pyramiding the Tax}

The imposition of a tax upon $B$, measured by the principal plus the tax sum, means of course that $B$ is subject to a further income tax on the amount of the tax sum. Carried one step further, there may be an additional tax imposed on this sum. At every step there may be a further tax imposed on the preceding tax sum. Now if $A$ is obligated to pay all the income taxes of $\mathrm{B}$, arising out of the initial payment, the ultimate obligation of $\mathrm{A}$ might be extremely burden-

11. Durkee v. Comm'r, 162 F. 2d 184 (C. C. A. 6th 1947).

12. Old Colony Trust Company v. Comm'r, 279 U. S. 716 (1929) ; C. B. Levey, 26 B. T. A. 889 (1932) aff'd 68 F. 2d 401 (App. D. C. 1933); Noel v. Parrott, 15 F. 2d 669 (C. C. A. 4 th 1926).

13. Magill, Taxable Income 293-305 (rev. ed. 1936).

14. Rogan v. Mertens, 153 F. $2 d 937$ (C. C. A. 9th 1946), affirming 56 F. Supp. 450 (S. D. Cal. 1944); Northern Ohio Ry., C. C. H. T. C. REP. Dec. 16,141 (M) (1947); see Acer Realty Co., P-H 1944 T. C. Men. Dec. Serv. $\Uparrow 44,143$ (1944).

15. See Providence v. Worcester R. R., 5 B. T. A. 1186 (1927) (the taxpayer did not succeed in regarding the payment as a contribution to capital).

16. Kinnicutt, P-H 1943 T. C. Mem. Dec. Serv. \43,449 (1943). 
some. ${ }^{17}$ The taxpayer in Old Colony Trust Company, ${ }^{18}$ realizing this possibility, used it as an argument against imposing any tax: "It is next argued against the payment of this tax that if these payments by the employer constitute income to the employee, the employer will be called upon to pay the tax imposed upon this additional income, and that the payment of the additional tax will create further income which will in turn be subject to tax, with the result that there would be a $\operatorname{tax}$ upon a tax. This it is urged is the result of the Government's theory, when carried to its logical conclusion, and results in an absurdity which Congress could not have contemplated." 19 The Court neatly avoided the problem, saying: "In the first place, no attempt has been made by the Treasury to collect further taxes, upon the theory that the payment of the additional taxes creates further income, and the question of a tax upon a tax was not before the Circuit Court of Appeals and has not been certified to this Court. We can settle questions of that sort when an attempt to impose a tax upon a tax is undertaken but not now. . . . It is not, therefore, necessary to answer the argument based upon an algebraic formula to reach the amount of taxes due." 20

No case has been found which goes further than to impose a tax upon the first tax. ${ }^{21}$ One case indicates that the Collector apparently sought to pyramid the tax, but the Court's opinion went to some length to demonstrate that such "pyramidal grasping" is "unwarranted." 22

17. Suppose that B's income puts him in an eighty per cent bracket, that B's tax bracket remains constant, and that the initial $T$ payment is $\$ 1,000$. The tax on $\$ 1,000$ is $\$ 800$. The tax on $\$ 800$ is $\$ 640$. The tax on $\$ 640$ is $\$ 512$. The tax on $\$ 512$ is $\$ 459.60$, etc. A will be obligated to pay the sum of this resulting calculation. Theoretically this presents an infinite series of "tax on tax" although each succeeding term approaches zero more closely than the preceding one. From a mathematical standpoint, the sum of this series is limited to a definite amount according to the formula in which the total sum of the series equals a/1-r. "a" represents the initial $T$ payment; " $r$ " the common ratio or the constant rate of tax (always less than $100 \%$ ). Thus, in the example given, the total tax would be $\$ 1000 / 1-.80$, or $\$ 1000 \% 2$, or $\$ 5000$.

18. 279 U. S. 716 (1929).

19. Id. at 730 .

20. Id. at 731 .

21. The extent of the tax thus far imposed can be illustrated as follows: A pays the sum $\mathrm{P}$ to $\mathrm{B}$. This creates an income tax represented by the symbol $T$. The Government has been successful in imposing an income tax created by the sum $T$. Thus $B$ is obligated to pay a tax measured by the tax created by $T$. The pyramid has gone no further, apparently, even though $A$ pays to $B$, not only $P$ plus $T$, but also the tax imposed on $T$. Pyramiding of the tax was considered in United States v. Boston \& M. R. R., 279 U. S. 732 (1929) (the Court said, "More than this, it should be added that neither before nor since 1923 has any algebraic formula been used by the Bureau in computing taxes." p. 736) ; Cincinnati v. Cincinnati N. O. \& T. P. Ry., 49 Ohio Abst. 1, 75 N. E. 2d 200 (1947) ; Providence \& Worcester R. R.. 5 B. T. A. 1186 (1927); Rogan v. Mertens, 153 F. 2d 937 (C. C. A. 9th 1946) (the court considered the pyramiding problem in relation to cash and accrual basis taxpayers).

22. Rogan v. Mertens, 153 F. 2 d 937 (C. C. A. 9th 1946). 
Doubt may well exist whether the use of a tax-shifting covenant might not at some future time subject a taxpayer to a pyramided tax liability. Essentially the risk is present where A covenants to pay all of B's taxes. The construction of the pyramid can be stopped if A's promise to pay B's taxes falls short of a promise to pay all of B's tax. A may covenant to pay only the amount of B's taxes measured by the initial tax on the single sum, $P$, rather than by all the taxes resulting from the payment of $P$. Or, $A$ can covenant that his maximum liability to $B$ will be a fixed sum of dollars. If A's maximum liability is fixed by formula or by a stated amount, B may of course be required to pay some amount of his own taxes. ${ }^{23}$ Even so, the amount which $B$ may then be required to pay will be less than $B$ would have been obligated to pay if there were no tax-shifting covenant. To the extent that $B$ appreciates the pyramidal risk to which $A$ might be subjected if $B$ insists that A covenant to pay all of B's taxes, $B$ may be willing to permit $A$ to limit the latter's obligation.

\section{OTHER TAX InCIDENTS}

Kind of income: Whenever it is determined that the payment of the tax sum is income to $B$, other problems, familiar in the tax field, arise. Income may be either ordinary income or capital gain. It can be premised that wherever the tax sum is the same character as the principal sum; the tax sum will be ordinary income if the principal sum is ordinary income. Thus, in the typical situation, salary or rent being ordinary income to $B$, the tax sum is likewise ordinary income.

Tax-shifting covenants, however, need not be confined to situations in which the principal sum is ordinary income. For example, a seller, B, might be willing to sell Blackacre for $\$ 200,000$ if he is assured of a long-term capital gain. A may agree to purchase Blackacre and further agree to pay all of B's income taxes arising from the resulting gain. Suppose that B's basis for gain or loss of Blackacre is $\$ 120,000$. If $B$ were to sell the property for $\$ 200,000$ and a longterm gain were to result, B's maximum tax would be $25 \%$ of $\$ 80,000$, or $\$ 20,000$. Thus $B$ would net $\$ 180,000$ after taxes.

$\mathrm{B}$ may endeavor to accomplish the desired result by insisting upon a net price of $\$ 180,000$ and require, in addition, that $A$ pay all of B's taxes. Even though the sale itself may result in a long-term capital gain, the problem arises as to whether the tax sum which $A$ agrees to pay is ordinary income to $B$, or whether the tax sum increases the purchase price and thus results in additional capital gain.

23. If $A$, for example, agrees to pay only the initial $T$ amount, then $B$ will be required to pay the tax based upon $T$. Since A's liability to $B$ is thereby limited, $B$ can not be reimbursed by $A$. 
The tax sum might be regarded as ordinary income to $B$ on the theory that income taxes are a debt, and that a promise by $A$ to pay the debt of $B$ results in ordinary income to $B .{ }^{24}$ The effect of the arrangement would then be that $A^{\prime}$ agrees to pay $\$ 180,000$ as the purchase price plus the long-term capital gains tax which is then $\$ 15,000$ ( $25 \%$ of $\$ 60,000)$. This appears, on the surface, to be a saving of $\$ 5,000$. However, since it is assumed that the $\$ 15,000$ is ordinary income, A would, in undertaking to pay all of B's taxes, be further obligated to pay B's income tax on the $\$ 15,000$. Even without further pyramiding, the total resulting cost to A would then ordinarily be in excess of $\$ 200,000 .^{25}$

It might be contended, however, that the tax sum which $A$ is obligated to pay is part of the purchase price. ${ }^{26}$ In such event, the formula is somewhat more complicated. The price is $\$ 180,000$ plus the tax sum. The formula for $T$ is the sum of the gain $(\$ 60,000)$ plus $\mathrm{T}$, times the tax rate of $25 \%$. Thus $\mathrm{T}$ equals $\$ 20,000 .{ }^{27}$ Hence, if $\mathrm{T}$ is regarded as part of the purchase price, A would pay $\$ 180,000$ plus a tax sum of $\$ 20,000$. However, the tax sum of $\$ 20,000$ would likely be regarded as income to $B$ on which the Government could assert a further tax. If $A$ agrees to pay all of $B$ 's taxes resulting from the sale, then $A$ would be further obligated to pay an income tax on the $\$ 20,000$, subject also to the risk of "pyramidal grasping." 28

Neither of the above two alternatives is satisfactory because each subjects $A$ to a possible liability in excess of $\$ 200,000$ even if the sale is recognized as a long-term capital gain.

The better method for giving the parties the desired result is one in which the buyer, $A$, agrees to pay $\$ 200,000$ as the purchase price and further agrees to indemnify the seller, $\mathrm{B}$, if the seller's income tax on the $\$ 200,000$ sale is more than $\$ 20,000$. In the event that the transaction is recognized as giving rise to long-term capital gain, A's

24. Bergen v. Commissioner, 80 F. 2d 89 (C. C. A. 2d 1935) (payment by a trustee of a beneficiary's income tax).

25. In the event that the parties should seek to curtail the pyramiding of the tax by limiting A's liability to the first tax, B would be obligated to pay some income tax. B's net gain is then less than $\$ 180,000$. Thus, even if the gain is recognized as long term but A's liability is limited to the $\$ 15,000 \operatorname{tax}$, B would be required to regard the $\$ 15,000$ as ordinary income and pay a tax thereon.

26. Iash's Products Co. v. United States, 278 U. S. 175 (1928); Acme Coal Co. v. United States, 44 F. 2d 95 (Ct. Cl. 1930); Pennsylvania Forge Corp., P-H 1943 T. C. Mem. Dec. Serv. $\llbracket 43,409$ (1943). See also 5 Mertens, Federal Inconre TAxation 9 (1942).

27. The gain is the difference between $\$ 180,000$ and $\$ 120,000$ or $\$ 60,000$. The minimum tax rate on a long term capital gain is commonly referred to as $25 \%$ of the gain. (More accurately, of course, a long term capital gain is calculated upon only $50 \%$ of the actual gain with a maximum tax rate thereon of $50 \%$.) Thus, $T$ equals the tax rate multiplied by the sum of the gain and $T$. In this instance, $T$ equals $25 \%$ of $\$ 60,000$ added to $T$. $T$, therefore, equals $\$ 20,000$.

28. In the event that the parties should seek to limit A's liability, $B$ would not realize a net of $\$ 80,000$ since $B$ would be obligated to pay a tax. See note 23 , supra. 
complete obligation is discharged by the payment of $\$ 200,000$ and B's net is $\$ 180,000$. However, if the sale should not be regarded as giving rise to long-term capital gain, B would be obligated to pay an income tax calculated on the basis of ordinary income. If the tax to $B$ on this ordinary income is, for example, $\$ 50,000, A$, in agreeing to pay all of $B$ 's taxes, would then be obligated to pay an additional sum sufficient to net $B$ the $\$ 50,000$. In such event, $A$ will be obligated to pay sums in addition to the $\$ 200,000$, but this is the very risk which $\mathrm{A}$, it is premised, has agreed to assume.

When is income realized: The customary distinction between cash and accrual basis taxpayers is applicable to the time for reporting any income which may be realized as a result of tax-shifting covenants. A cash basis taxpayer realizes income in the year of actual or constructive receipt. Thus, on a cash basis, $B$ realizes income in the year in which A pays the principal sum and additional income in the year in which $A$ pays the tax sum. ${ }^{29}$

An accrual basis taxpayer realizes income in the year in which the income is earned, regardless of the year the contract was made or the year the promise is to be performed. ${ }^{30}$ The special problem arising from tax-shifting covenants is to determine whether the income is earned at or before the close of the obligee's tax year, or earned in the year in which the obligee, $B$, is required to file his tax return. Some cases hold that the obligee realizes income in the year he is required to file his return and pay his tax. ${ }^{31}$ These cases, however, ignore the fact that logically the income is realized during the year of the transaction and the income tax can be considered as fixed and determinable as of the last moment prior to the close of the year in which the transaction occurred. All the events necessary to establish the fact of income tax liability and the amount thereof occur in the year preceding the filing of the return. ${ }^{32}$

The nature of the payment: Thus far we have considered the tax effect upon $B$, the recipient of the tax sum payment by $A$. The tax effect upon $A$, the paying party, is equally important. In general, the tax sum will be deductible as an ordinary and necessary expense if

29. Nunnally Investment Co. v. United States, 36 F. Supp. 332 (Ct. Cl. 1941) ; Wallin Coal Corp. v. Comm'r, 71 F. 2d 521 (C. C. A. 4th 1934); C. B. Shaffer, 29 B. T. A. 1315 (1934).

30. Commissioner v. Terre Haute Electric Co., 67 F. $2 d 697$ (C. C. A. 7th 1933).

31. Providence \& Worcester R. R., 5 B. T. A. 1186 (1927); Comm'r v. Terre Haute Electric Co., 67 F. 2d 697 (C. C. A. 7th 1933), reversing 24 B. T. A. 197 (1931) ; Ware River R. R., 7 B. T. A. 133 (1937).

32. Continental Tie \& Lumber Co. v. United States, 286 U. S. 290 (1932); S. M. Goldstein Co., 16 B. T. A. 1269 (1929). See Durst Productions Corp. v. Comm'r, C. C. H. T. C. Dec. 2107 (1947); G. C. M. 25298, 1947 INT. Rev. Bull. No. 16 at 2 (1947); A. R. M. 16, 2 Cun. Bull. 62 (1920). 
the principal sum is so deductible. Thus if an employer, A, pays a salary to $B$, which is deductible as an ordinary and necessary business expense, the payment of B's income tax, the tax sum, being additional salary, will likewise be deductible if reasonable in amount. ${ }^{33}$ A tenant who is permitted to deduct the rent as an ordinary and necessary business expense will likewise be permitted to deduct the tax payment. ${ }^{34}$ However, if the principal sum is not a deductible item (for example, residential rent), the further payment of the landlord's tax is not deductible. ${ }^{35}$

The rule that Federal income taxes are not deductible does not bar the deduction where the payment is occasioned by a tax-shifting covenant. The rule is that Federal income taxes may not be deducted by the taxpayer. Since the taxpayer is $B$, not $A, A$ is not barred from the deduction because of this principle. ${ }^{36}$

In the absence of a binding tax-shifting covenant, A's position is precarious. If $\mathrm{A}$ is not obligated to pay the tax sum, but does so "voluntarily," then it has been held that the payment is not deductible. ${ }^{37}$ If a tenant, for example, is not bound to pay the landlord's taxes but nevertheless does so, the tenant may not deduct the payment. ${ }^{38}$ The tenant might have a cause of action against the landlord for the return of the rent thus paid either on the theory that the payment is a loan ${ }^{39}$ or on the theory that the payment was made under mistake. In neither event would the payment be deductible. Of course, if the payment is a gift, ${ }^{40}$ an unlikely possibility, the payment is neither deductible for income tax purposes nor refundable to the tenant.

The customary line of demarcation between capital expenditures and deductible expenses applies equally well here. In those situations where payment of the principal obligation is a part of the purchase price of property, the additional tax payment should be regarded as additional price and added to the cost. ${ }^{41}$ While a purchaser might desire to consider such additional obligation as an expense, rather than to capitalize it, the character of the payment should be determined by

33. A. W. Hurley, 6 B. T. A. 695 (1927) ; I. T. 1388, I-2 Cur. Bull. 97 (1922). But see Wilkenfield, Net Salaries-A Poor Risk, 24 TAxes 1150 (1946).

34. U. S. Treas. Reg. 111, $\$ 29.23$ (a)-10 (1943); Denholm \& McKay Co., 39 B. T. A. 767 (1939).

35. See Caroline T. Kissel, 15 B. T. A. 1270 (1929).

36. 5 Mertens, Federal Income Taxation 6 (1942).

37. Thomas Flexible Coupling Co., P-H 1944 T. C. Mem. Dec. Serv. II 44,190 (1944), aff'd, 158 F. 2d 828 (C. C. A. 3d 1946), cert. denied, 329 U. S. 810 (1946); 4 Mertens, Federal income Taxation, 328 (1942).

38. W. N. Robinson v. Comm'r, 53 F. 2 d 810 (C. C. A. 8th 1931).

39. See Leicht v. Comm'r, 137 F. 2 d 433 (C. C. A. 8th 1943).

40. See Leicht v. Comm'r, 137 F. $2 d 433$ (C. C. A. 8th 1943).

41. 5 Mertens, Federal Income Taxation 9 (1942). 
the real nature of the transaction rather than by the desires of the parties.

When is the payment deductible: Assuming that the payment is deductible, it is essential to determine the year in which the deduction may be taken. For a cash basis taxpayer, the answer is relatively simple: the deduction is taken in the year of payment.

The general rule as to an accrual basis taxpayer is to deduct an item in the year in which all events have occurred which fix the amount and fact of liability, rather than in the year when payment is due. ${ }^{42}$ The obligation of A to pay B's income tax is of course contingent upon B's obligation to pay such a tax. The income tax is not a "transaction tax" like a sales tax. As a consequence, the obligation to pay an income tax is not ascertainable until at least the close of business for the tax year. Whether the deduction may be taken in the tax year in which the transaction occurred or in the following year when $B$, the taxpayer, is required to file his return, has not been clarified. It would seem that the deduction should be taken in the year the transaction has occurred unless there is to be a bona fide contest to test the fact of liability. ${ }^{43}$

\section{Shift to the Receiving Party}

Thus far, we have considered a tax-shifting covenant in which one party, $A$, pays to the other, $B$, in addition to the principal sum involved, an additional sum for B's income taxes thereon. Such taxshifting covenant may arise, as indicated, either because $B$ insists upon a net deal to himself, or because $B$ insists that $A$ absorb income tax uncertainties. These same business factors may play an important role where the transaction starts on a different footing.

A taxpayer may be willing to incur an expense if he is assured that the expense is a deductible item. An employer may be willing to pay a high salary to an employee provided the employer is permitted to deduct the entire salary. A husband may be willing to pay his estranged wife relatively high alimony provided he is assured that he will be permitted to deduct the payments. A tenant may agree to pay a requested rental if the rent payments are deductible. In these situa-

42. The Aluminum Castings Co. v. Routzahn; 282 U. S. 92 (1930); American National Co. v. United States, 274 U. S. 99 (1927); United States v. Anderson, 269 U. S. 422 (1926); See Dixie Pine Products Co. v. Comm'r, 320 U. S. 516 (1943) ; 5 Miertens, Federal Income Taxation 80 (1942).

43. Dixie Pine Products Co. v. Comm'r, 320 U. S. 516 (1944) ; G. C. M. 25298, 1947 Int. Rev. Buli. No. 16 at 2 (1947). 
tions the problem is that of assuring the paying party that his payment is deductible as compared with the previously discussed situations in which the receiving party desires to be assured that the received amount is net to him. In order to accomplish the desired result, the receiving party may covenant to reimburse the paying party in the event that the paying party will not be permitted to deduct the payment. Not only are all of the tax implications heretofore considered present, but further tax consequences become apparent.

For the sake of convenience, the following designations are adopted. $\mathrm{X}$ is the person making the principal payment to $\mathrm{Y} . \mathrm{Y}$ agrees to reimburse $X$ in the event that $X$ is not permitted to deduct the full amount of the principal sum. The amount of the reimbursement should be so calculated that whether or not $\mathrm{X}$ is permitted to deduct the entire sum, the net cost to $X$ will be one anticipated sum.

Suppose in a typical case that an employer would be willing to pay an employee $\$ 20,000$ per year should the sum be wholly deductible, but that it is doubtful that more than $\$ 12,000$ per year will be allowed as a deduction. If the employer loses the benefit of the deduction to the extent of $\$ 8,000$, he will pay, if a corporate taxpayer in the $38 \%$ corporation bracket, $\$ 3,040$ additional in taxes. If the employee were to hold the employer wholly free of tax loss, he would be obligated to reimburse the employer in an amount sufficient to net the employer $\$ 3,040$. It might be contended that the payment of any sum by the employee, $\mathrm{Y}$, to the employer, $\mathrm{X}$, is income to the employer. If this contention were sustained, the employee would be obligated to pay $\$ 3,040$ plus the employer's additional tax on this $\$ 3,040$.

The receipt of income: It has generally been held that income is taxable in the year in which received even though in a later year the taxpayer may be obligated to refund the amount received in whole or in part. ${ }^{44}$ The rule is stated in the leading case, North American Oil

44. North American Oil Consolidated v. Burnet, 286 U. S. 417 (1932) (income from the sale of oil and gas received by the taxpayer at a time when pending litigation might have required the restoration of the income received); Saunders v. Comm'r, 101 F. $2 \mathrm{~d} 407$ (C. C. A. 10th 1939) (taxpayers were held to have received commissions under a claim of right and therefore were required to report such commissions as income when received, although the commissions were later restored when suit was instituted for recovery of the commissions upon the ground that taxpayers had no legal right to the commissions); Griffin v. Smith, $101 \mathrm{~F}$. 2d 348 (C. C. A. 7th 1938) (taxpayers, officers of a corporation, were required to report the entire amount of salaries received as income although, upon claim of minority stockholders that salaries were in excess of a reasonable figure, taxpayers later restored a portion of the salaries received); Alfred J. Fleischer, 14 P-H $1945 \mathrm{~T}$. C. MEAr. DEC. SERv. If 45,380 (1945) (original compensation was partially disallowed to the employer as being unreasonable and the part restored had created a corporate deficit). See 2 Mertens, Federal Income TAXation 8 (1942). For a collection of cases, see Note, 154 A. L. R. 1276 (1945). 
Consolidated $v$. Burnet: ${ }^{45}$ "If a taxpayer received earnings under a claim of right and without restriction as to its disposition, he has received income which he is required to return, even though it may still be claimed that he is not entitled to retain the money, and even though he may still be adjudged liable to restore its equivalent." 46 If for no other reason, the practical necessities of income tax accounting customarily require such result. ${ }^{47}$ A different result would give rise to difficulties in the administration of the income tax especially where the amount which the taxpayer is required to restore can not be determined until some later year. ${ }^{48}$

Thus the entire amount, $\mathrm{P}$, should be regarded as taxable income though subject to possible partial restoration. Nevertheless, in Eakins v. United States, ${ }^{49}$ decided prior to North American Oil Consolidated, the court held that the amount of salary received by an employee under an obligation to restore any portion disallowed by the Commissioner because not reasonable was not taxable income as to such portion when received by the employee. ${ }^{50}$ The decision in the Eakins case overlooks the practical difficulties of income tax administration. The better approach would seem to be to regard the entire amount originally received as income at that time but to permit the taxpayer a deduction in the later year upon repayment. ${ }^{51}$ Such approach may result in an advantage or disadvantage to the taxpayer, depending on the difference, if any, in his tax bracket between the year of receipt and the year of restoration. Perhaps this possible hardship to the taxpayer motivated the Court of Claims in a recent case ${ }^{52}$ to award the

45. 286 U. S. 417 (1932).

46. Id. at 424 .

47. Penn v. Robertson, 115 F. $2 d 167$ (C. C. A. 4th 1940).

48. If the taxpayer were permitted to reduce his taxable income by the amount he might be required to restore, there is no practical means for determining the reduced figure until a later year. Furthermore, if the taxpayer vere required to and did report the entire sum as income when received, a refund claim might be ineffective.

A claim for refund must be filed within a limited time, INT. REv. CoDE, Sec. 322(b) (1); hence the taxpayer may be barred from filing a refund claim. The taxpayer can not always be assured that he will know the amount of the refund claim until the time within which he should have filed his claim will have expired.

49. 36 F. 2d 961 (E. D. N. Y. 1930).

50. The Tax Court held to the contrary in Alfred J. Fleischer, 14 P-H 1945 T. C. MEMr. DEC. SERv. If 45,380 (1945), differentiating the cases partly upon the fact that in the Eakins case the taxpayer was obligated contractually to restore the excessive compensation whereas the taxpayer in Alfred J. Fleischer had not contracted to restore. But the taxpayer who contracts to restore probably should be in a worse position than one who does not.

51. Penn v. Robertson, 115 F. 2d 167 (C. C. A. 4th 1940) ; Burnet v. Sanford \& Brooks Co., 282 U. S. 359 (1931).

52. Gargaro v. United States, 73 F. Supp. 973 (C. Cl. 1947) (one dissent). The taxpayer may, of course be in a higher tax bracket in the later year and thus gain a financial advantage if permitted a deduction in the year of restoration. It is not always clear that the restored amount will be treated as deductible expense. The possibility exists that it may be treated as a loss. Noted at 61 Harv. L. REv. 710

(1948). See 2 Mertens, Federal Income Taxation 136 N. 62 (1942). 
taxpayer, an employee, a refund where his compensation was based upon a percentage of the employer's profits, which profits were renegotiated. The Court of Claims in reaching this result placed some reliance upon the theory that the payments were made under an honest mistake that the taxpayer (employee) was not entitled to the entire amount received. ${ }^{53}$

Regardless of the validity of allowing the taxpayer a refund in cases where the obligation to restore is occasioned by an honest mistake or by renegotiation, the "claim of right" theory should be persuasive in the case of income received under the circumstances here discussed. ${ }^{54}$

The deduction of the principal sum by $X$ is interrelated with the possible reimbursement by $Y^{55}$ The theory of annual accountings here, as elsewhere, ${ }^{56}$ requires a practical determination of the year in which the deduction will be allowed. Thus, as a practical matter, at least, the deduction by $\mathrm{X}$ should be allowed in the year "paid or accrued" or "paid or incurred" regardless of possible reimbursement by $\mathrm{Y}$ in a later year. ${ }^{57}$

The tax-shifting covenant is made a part of the arrangement between $\mathrm{X}$ and $\mathrm{Y}$ because of some doubt that the principal sum may be deductible by $X$. Upon the Government's subsequent examination of $X$ 's income tax return, the tax-shifting covenant may heighten inquiry into the deductibility of the principal sum. Where, for example, $P$ represents a salary payment, the fact that the parties have entered into a tax-shifting covenant may tend to show that the parties themselves had doubt as to whether the salary was reasonable in amount at the outset. Essentially, the propriety of a deduction should be based on objective factors not connected with the reimbursement provision. The real purpose of a reimbursement provision is to shift the payment of a tax deficiency if a tax deficiency should be assessed. The fact that one party seeks to lessen the risk of liability for such potential tax

53. Greenwald v. United States, 57 F. Supp. 569 (Ct. C1. 1944). (The employee received a bonus computed upon profits greatly in excess of actual profits. The auditors had falsified the records. The employee was successful in a suit for refund); Knight Newspapers v. Comm'r, 143 F. 2d 1007 (C. C. A. 6th 1942).

54. Where a taxpayer restores a portion of the income in the same year it was received, it was held however, that the taxpayer need only report the amount retained by him. Smucker v. Comm'r, C. C. H. T. C. Rep. Dec. 16,057 (M) (1947).

55. It is assumed that the $P$ sum is of the type and character which is deductible. If the $P$ sum is not deductible (if it is, for example, a personal non-deductible expense), then there is no need to inquire into the effect of possible reimbursement.

56. Note 47 supra.

57. However, where at the time payment of $P$ is made, $X$ and $X$ understand that the entire amount is to be returned, then, the court in Maggio Bros. Co., 6 T. C. 999 (1946) held, no part of $P$ is allowed as a deduction. 
deficiency should not create a greater risk that the deduction will be disallowed. ${ }^{58}$

The tax effects of reimbursement: The reimbursement is essentially the same as the payment by one person of another's income tax. The agreement to reimburse should have the same tax consequences as the types of agreements to pay another's income taxes already considered. ${ }^{59}$ The time when income is realized by a cash or accrual basis taxpayer has been discussed. ${ }^{60}$ The cash basis taxpayer presents little difficulty. Income is taxable in the year it is actually or constructively received.

An accrual basis taxpayer has taxable income in the year when the obligation becomes fixed. The obligation to reimburse, however, does not become sufficiently fixed to be regarded as income at the time when the tax-shifting covenant is, executed since it is then too uncertain whether any obligation to reimburse will ever become operative. ${ }^{61}$ The obligation to reimburse can be fixed only when the deduction to $\mathrm{X}$ is disallowed. ${ }^{62}$

$\mathrm{Y}$ will of course seek to deduct the reimbursed sum. In most instances the allowance of the deduction will turn on whether the expense is an "ordinary and necessary" one incurred in the "course of trade or business." An obligation by an employee who agrees to repay his employer a portion of the salary received would seem to be an obligation arising out of the employee's trade or business. ${ }^{63}$

A reimbursement covenant in a lease in which the landlord agrees to reimburse the tenant in the event that the tenant is disallowed rent as a deduction should give the landlord an allowable deduction when the clause comes into operation. Such an expense, though unusual, should be regarded as an ordinary and necessary business expense arising from the receipt of taxable rental income.

A reimbursement covenant in a property settlement agreement may give rise to different income tax consequences. If the divorced

58. It should be noted that $X$ still runs a risk of payment of the deficiency. The deficiency will normally not be determined for a period of years after the event. $Y$ may have become insolvent. Furthermore the tax shifting covenant may be limited in the amount of the reimbursement so that $Y$ does not agree to pay all of $X$ 's tax deficiency. In fact it is inadvisable for $Y$ to agree to pay all of $X$ 's tax deficiency; supra p. 826.

59. Supra page 823.

60. Supra page 828 .

61. 2 Mertens, Federal Income Taxation 212 et seq. (1942).

62. Comm'r v. Terre Haute Electric Co., 67 F. 2d 697 (C. C. A. 7th 1933), reversing 24 B. T. A. 197 (1931).

63. See O. D. 1009, 5 Cum. Burl. 81 (1921) (compensation earned by employee from debtor of employer and turned over to employer may be deducted by employee as a business expense); O. D. 579, 3 CUM. BuLL. 130 (1920) (fees paid to secure employment are allowable deductions by an employee). 
wife is obligated to reimburse her former husband where the husband is disallowed alimony payments as a deduction, the repayment by the wife may not be deductible by her. ${ }^{64}$

\section{Rights Between the Parties and the Governatent}

Assume that a promisor has agreed to pay the promisee's income tax arising out of a transaction and that the transaction, entered into in January, results in net taxable income of $\$ 1,000$. Suppose the promisee thereafter obtains taxable income from other sources so that at the end of the year the promisee has sufficient income to put him in a $50 \%$ bracket. Is the promisor obligated to pay $50 \%$ of $\$ 1,000$, or some lesser sum or perhaps nothing at all ${ }^{65}$ Needless to say, a taxshifting covenant should define the percentage which the promisor is obligated to pay. The covenant could provide a maximum percentage or could provide a formula under which the amount of tax which the promisor is to pay bears the same relation to the promisee's total income tax as the income from the transaction bears to the promisee's total income. Furthermore the promisor should consider it beneficial to limit his obligation to a fixed maximum amount. Such fixed maximum amount is not only advisable as a normal business precaution but also as a safeguard against any possible pyramiding of tax liability. ${ }^{66}$

A tax-shifting covenant may be expressly worded so that the obligation of the promisor does not mature until the promisee has paid his income taxes. Payment of the taxes by the promisee would seem under such a covenant a condition precedent to the promisee's right of recovery against the promisor. ${ }^{67}$

A tax-shifting covenant may, in addition, be worded so that the obligation of the promisor is premised on income taxes which are validly owed by the promisee. In an action against the promisor, the promisee may then have the burden of proving that the income taxes were properly due the Government.

Tax-shifting covenants may be written so as to provide that the promisor will pay the promisee's taxes directly to the Government. ${ }^{68}$ Whether, in such event, the promisee will have a cause of action for

64. See Rudick, Marriage, Divorce and Taxes, 2 TAx L. Rev. 123 (1947); I. T. 3856, 1947 INT. REv. Bull. No. 13 at 3 (1947) (counsel fees paid by wife in suit to obtain increase in alimony are not deductible).

65. The promisor might be obligated to pay nothing if the promisor is obligated to pay the promisee's tax on only the "first" income received.

66. See p. 826 supra.

67. WIlliston, Contracts $\$ 675$ (rev. ed., Williston and Thompson, 1936). Sth 1948).

68. United States v. Scott, 5 C. C. H. 1948 FEd. TAx Rep. $\llbracket 9193$ (C. C. A. 
failure to pay depends upon the law of contracts in each jurisdiction. ${ }^{69}$ Since for income tax purposes no distinction is made between the promisor's obligation to pay the promisee's income taxes directly to the promisee or to pay to the Government, ${ }^{70}$ the promisee will ordinarily prefer that the promisor be directly obligated to the promisee.

Where the promisor fails to pay the promisee the amount of income taxes agreed to be paid, a cause of action for breach materializes. Of course, the obligation to pay another's tax must be expressed in the contract in sufficient form to give rise to the obligation. ${ }^{71}$ It should be noted that tax-shifting covenants may go further than to provide for the payment of the tax arising out of a particular transaction and may, where the buyer acquires all of the seller's business and good will, provide for payment of all the seller's debts including past due income taxes. ${ }^{72}$

In a sense, the promisor is much like an insurer. The promisor agrees to pay if there is income tax liability. In normal commercial transactions an insurer or guarantor seeks the right to defend the fundamental liability. Thus, if A agrees to pay B's taxes, A might seek to defend the Government's assertion of tax liability upon B. In commercial transactions, an insurer by contract creates the right to defend claims. Probably, it is permissible for the parties to provide that the promisor may undertake the defense or prosecution of all matters relating to the income taxes involved.

A taxpayer can not immunize himself from tax liability upon the ground that another has promised to pay his taxes. ${ }^{73}$ Thus, the presence of a tax-shifting covenant can not serve to avoid government tax procedures for the enforcement of income tax liability. The promisee still remains the taxpayer subject to Governmental processes.

69. 2 WILLISTON op. cit supra note $67, \S 390$.

70. Bergan v. Comm'r, 80 F. 2d 89 (C. C. A. 2d 1935).

71. Western Union Tel. Co. v. Pacific \& At1. Tel. Co., 297 N. Y. 124, 75 N. E. 2d 843 (1947) (lessee not obligated to pay lessor's income tax on rent); Cincinnati v. Cincinnati, N. O. \& T. P. Ry., 49 Ohio Abst. 1, 75 N. E. 2d 200 (1947) (lessee held obligated to pay lessor's income tax on rent). See also Note, $140 \mathrm{~A}$. L. R. 517 (1942).

72. Continental Baking Co. v. Comm'r, 75 F. $2 d 243$ (App. D. C. 1934), affirming 27 B. T. A. 884 (1933), cert. denied 295 U. S. 756 (1934); American Equitable Assurance Co. v. Comm'r, $68 \mathrm{~F} .2 \mathrm{~d} 46$ (C. C. A. 2d 1933), affirming 27 B. T. A. 247 (1932) ; Georgia, F. \& A. R. R., 31 B. T. A. 1 (1934); United States Trucking Corp., 29 B. T. A. 940 (1934); see The Sample Furniture Shops, Inc. v. Comm'r, 123 F. 2d 90, 92 (C. C. A. 4th 1941) ; California Iron Yards Corp. v. Comm'r, 82 F. 2d 776, 779 (C. C. A. 9th 1936). But cf. Reid Ice Cream Corp. v. Comm'r, 59 F. 2d 189 (C. C. A. 2d 1932) where, however, the court found that the buyer did not agree to assume the taxes in question.

73. G. C. M. 659 V-2 CuM. BuLl. 79 (1926) ("A taxpayer may not, by a contract providing that a third person pay its taxes, force the Government to collect from such third person"). 
In fact, the validity of the tax-shifting covenant may be impaired if the parties endeavor to alter the taxpayer-Government relationship. ${ }^{74}$ The promisor, however, stands in the position of a third party obligor for the payment of the promisee's taxes, ${ }^{75}$ and subject to diversity of opinion ${ }^{76}$ may be liable to suit by the Government for the amount of the promisee's unpaid income taxes. ${ }^{77}$ In addition, where the transaction between the promisee and promisor involves the transfer of assets, then the promisee is liable as a transferee under section 311 of the Internal Revenue Code. ${ }^{78}$

There is no discussion in the cases hitherto cited concerning the validity of provisions in tax-shifting covenants. However, the problem of the validity of somewhat similar provisions has been before the courts. In Commissioner v. Procter, ${ }^{79}$ a donor provided in his trust indenture that if the gift were found to be subject to gift tax, then the gift should fail. That is, the donor sought by the condition in his gift indenture to defeat the gift if it were later determined that he made a taxable gift. The condition was held invalid. The reasoning of the Court, in part, was that to give effect to the condition would make impossible the collection of the gift tax. Thus the donor in the Procter case was not endeavoring to shift the burden of the tax; instead he attempted to defeat the gift, and therefore the tax, completely. ${ }^{80}$ This is not true of the income tax-shifting covenant which, on the contrary,

74. Bartels v. Birmingham, 332 U. S. 126 (1947), discussed infra p. 838.

75. United States v. Scott, 5 C. C. H. 1948 FEd. TAX Rep. $\pi 9193$ (C. C. A. Sth 1948). In the Scott case, the Government sought recovery based upon a tax shifting covenant. Suit was brought in the District Court of the United States for the Eastern District of Missouri, based upon a contract executed between a taxpayer and the defendant on June 8, 1936. The action was instituted on December 26, 1945. The statute of limitations in Missouri on any writing for the payment of money is ten years. The defendant moved to dismiss the complaint on the ground that the six year period of limitations in INT. REv. CoDE, $\$ 276$ (c), was controlling of the Government's right to sue a third party on the contract, and that the action therefore was barred as not having been commenced within the six year period. The trial court sustained the defendant's motion. Held: reversed. The court said that the defendant's liability "was not for taxes as such but for damages from breaching his obligation to satisfy a debt of the taxpayer. The provisions of the Internal Revenue Code do not make such an obligor a 'taxpayer'. Indeed, the Revenue Code does not even make mention of such a contractual liability, and we can find nothing in its language or purpose to impliedly suggest that Congress intended such independent and voluntary undertaking, which might operate in favor of the Government, to be in any way subject to the prescriptions and limitations of the Revenue statutes."

76. 2 WIILISTON op. cit. supra note $67 \S 393$.

77. But see Bartels v. Birmingham, 332 U. S. 126 (1947).

78. Cases cited note 72 supra.

79. 142 F. 2 d 824 (C. C. A. 4th 1944).

80. But cf. Stone v. Stone, 319 Mich. 194 (1947), in which the donor created a family partnership. This family partnership was not recognized for income tax purposes. An action was brought by the donor in the State court to declare the partnership gifts a nullity on the ground that the gifts were induced by mistake of fact and law. The court gave judgment for plaintiff. This case did not involve the validity of a tax shifting covenant. 
offers to the Government a greater possibility for the collection of the tax.

In Bartels v. Birmingham, ${ }^{81}$ the Supreme Court of the United States had before it a problem involving the social security tax. An agreement prescribed by the American Federation of Musicians was executed between a band leader and a dance hall operator. The agreement stated that the ballroom operator is the employer of the musicians and their leader and the operator "shall have complete control of the services which the employees will render under the specifications of this contract." The agreement therefore sought to make the individual musicians the employees of the operator rather than the employees of the orchestra leader, and thus subject the operator to pay the social security tax on the salaries of the musicians. The majority opinion stated, in part: "We do not think that such a contractual shift authorizes the Commissioner to collect taxes from one not covered by the taxing statutes." 82 The fundamental problem discussed by the Court was whether the status of an employer-employee can be shifted by contract. If the leader is in fact the employer, then, the Court held, the leader may not by contract make the operator the employer. The Court did not consider whether an operator might validly agree to reimburse the leader for social security taxes paid by the leader without attempting to change the status of the parties or substitute one taxpayer for another. Thus the validity of an income tax-shifting covenant remains unaffected by the Bartels case.

Indeed there seems no reason why an income tax-shifting covenant should be considered an invalid arrangement between the parties. An income tax-shifting covenant does not defeat the collection of a tax, nor does it seek to alter the relationship between the Government and the taxpayer. An income tax-shifting covenant serves only to determine, as between the parties, who shall have the ultimate burden of paying the tax. ${ }^{83}$

\section{CONCLUSION}

The reported cases, if they reflect the actual scope of use of the tax-shifting covenant, indicate that the covenant has been used in only a limited number of situations. While tax-shifting covenants have been used chiefly in employment contracts, leases, and somewhat in purchases of going businesses, the use of the covenant need not be so limited. Any situation in which differing tax opinions are expressed between parties negotiating a transaction can lend itself to a tax-

81. 332 U. S. 126 (1947).

82. Id. at 132 . 8th 1948).

83. United States v. Scott, 5 C. C. H. 1948 FED. TAX REP. I9193 (C. C. A. 
shifting covenant. For example, a partnership composed of $O$ and $P$ is about to organize a corporation. $P$ expresses the view that the transfer of the partnership assets into a corporation will not be a taxfree exchange. ${ }^{84} \mathrm{O}$ is advised differently. If $\mathrm{O}$ and $\mathrm{P}$ continue to disagree, then the transfer of the partnership assets into a corporation may not occur. $\mathrm{O}$ can break the deadlock by agreeing to indemnify $\mathrm{P}$ in the event that $P$ suffers a tax loss if the transfer is not recognized as a tax-free exchange. Again, $\mathrm{M}$ and $\mathrm{N}$ desire to form a corporation of minimum stock structure. The proposed corporation will require additional funds, which $M$ says can be loaned by the stockholders to the corporation. $\mathrm{N}$ is fearful that the loan will be treated as an additional capital investment for income tax purposes. $^{85}$ M. might covenant to protect $N$ against such income tax uncertainty.

A tax-shifting covenant, of course, has its limitations. In commercial transactions where a debtor owes money to a creditor, the debtor can effectively terminate his relations with his creditor if the debtor finds a third person who promises to, and does, pay his debt. A taxpayer cannot avoid remaining a taxpayer under similar circumstances, even though a third party pays his taxes. Not only does he remain a taxpayer, but additional income (hence additional tax) results to him as a consequence of a tax-shifting covenant.

Notwithstanding these general limitations, a tax-shifting covenant has a financial benefit to the person in whose favor it runs. Even if his income tax may not be paid in full, it can be paid in part. Even if he cannot, by a tax-shifting covenant, avoid all income tax uncertainties, he can avoid those which are the greater financial risks. And whenever differing tax opinions between negotiating parties tend to deadlock a transaction, a tax-shifting covenant may resolve the difficulty.

84. The Strouse, Adler Co., P-H 1944 T. C. MeMr. Dec. Serv. $\pi 44,219$ (1944) (tax free exchange recognized). See also Levy, The Incorporation of Partnerships, 25 TAXEs 43 (1947). (1943).

85. Joseph B. Thomas, 2 T. C. 193 (1943) ; Edward G. Janeway, 2 T. C. 197 